\title{
Nesting Biology of Odynerus albopictus calcaratus (Morawitz, 1885) and Odynerus femoratus de Saussure, 1856 (Hymenoptera: Vespidae: Eumeninae)
}

\author{
Alexander V. Fateryga ${ }^{1,2}$ \\ ${ }^{1}$ Karadag Nature Reserve, National Academy of Sciences of Ukraine, Nauki Street 24, Kurortnoye, Feodosiya 98188, Ukraine \\ ${ }^{2}$ Vernadsky Taurida National University, Academician Vernadsky Avenue 4, Simferopol 95007, Ukraine \\ Correspondence should be addressed to Alexander V. Fateryga; fater_84@list.ru
}

Received 19 March 2013; Revised 28 May 2013; Accepted 26 June 2013

Academic Editor: Gabriela Pérez-Lachaud

Copyright (C) 2013 Alexander V. Fateryga. This is an open access article distributed under the Creative Commons Attribution License, which permits unrestricted use, distribution, and reproduction in any medium, provided the original work is properly cited.

\begin{abstract}
The nesting biology of Odynerus albopictus calcaratus and Odynerus femoratus was studied in the Crimea (south of Ukraine); 46 nests of O. a. calcaratus and 18 nests of $O$. femoratus were examined. Both species nest on horizontal ground surfaces. The nests are vertical burrows surmounted by turrets. Females use water during nest construction and retrieve mud pellets from the nest burrow; these pellets are of two distinct sizes: small ones are used for the turret construction and big ones are dropped away. Females hunt for larvae of curculionid beetles of the genus Hypera. Completed nests are sealed with demolished turrets and nest burrows are usually entirely filled with mud. The nests of $O$. a. calcaratus contain 1-2 cells; the nests of $O$. femoratus contain 1-10 cells. The turrets of $O$. a. calcaratus are curved, and opened sideward; the turrets of $O$. femoratus are straight, and opened upward. The nesting success is $83 \%$ in O. a. calcaratus and 55\% in O. femoratus. Most of the wasps died due to abiotic factors (e.g., rain). The nest structures of the species in the genus Odynerus studied so far are compared, and the function of the nest turret is discussed.
\end{abstract}

\section{Introduction}

The genus Odynerus includes 45 species distributed mainly in the Palearctic region; only three Ethiopian species and four Nearctic ones are known [1-3]. The genus includes four subgenera, alphabetically: Allogymnomerus Blüthgen, 1951, Monoplomerus Blüthgen, 1941, Odynerus s. str., and Spinicoxa Blüthgen, 1938; the latter two are the most numerous and widespread $[1,4]$. Only Odynerus s. str. is distributed in all three regions while the other subgenera are strictly Palearctic.

Wasps of the genus Odynerus are well-known ground nesting eumenines. Réaumur's (1742) classic account on the nesting habits of Odynerus (s. str.) spinipes (Linnaeus, 1758) seems to be the earliest description of the biology of any Eumeninae [5]. The nests of Odynerus (Spinicoxa) reniformis (Gmelin, 1790) were described a century later by Fabre [6]. However, the majority of species in the genus has not been studied. Nevertheless, the nests of at least 10 species have been described for the present moment. Completed observations on the nesting substrate, nest construction, prey, parasites, and associates, as well as behavior of adults, are known for O. spinipes [7-11], O. reniformis [7, 9, 10, 12, 13], Odynerus (s. str.) dilectus de Saussure, 1870 [14, 15], and particularly for Odynerus (s. str.) melanocephalus (Gmelin, 1790) [7, 12]. Description of the nesting of Odynerus (Spinicoxa) eburneofasciatus Dusmet, 1903, with timekeeping of the female activity and good pictures was published by Haeseler [16]. Three other species, Odynerus (s. str.) alpinus Schulthess, 1897, Odynerus (s. str.) poecilus de Saussure, 1856, and Odynerus (Spinicoxa) simillimus Morawitz, 1867, were only briefly studied in respect of their nesting substrates and parasites, which were summarized by Blüthgen [17] and Amolin [3].

All species listed previously are "classical" ground nesting and turret ("chimney") constructing wasps. They excavate nest burrows on horizontal, vertical, or both horizontal and vertical ground surfaces and build one or several cells inside. Water is used by females to steep solid substrate and to make a mud mortar during the excavation and turret construction works. 
Most species of Odynerus hunt for curculionid larvae of the genus Hypera Germar, 1817 (Coleoptera: Curculionidae). However, Odynerus (s. str.) erythrogaster Bohart, 1939, and Odynerus (s. str.) cinnabarinus Bohart, 1939, hunt for gelechiid moths caterpillars (Lepidoptera: Gelechiidae) and nest in preexisting holes in trap stems, do not use water during the building works, and do not construct turrets [18].

The purpose of this paper is to describe the nesting biology of two species of Odynerus, discovered in the Crimea (south of Ukraine): Odynerus albopictus calcaratus (Morawitz, 1885) and Odynerus femoratus de Saussure, 1856. These species were not previously studied bionomically despite their broad ranges of distribution. Odynerus a. calcaratus is distributed in North Africa, Balkans, the Crimea, Asia Minor, Middle East, Transcaucasia, and Central Asia; O. femoratus is known also from West, Central, and South Europe, Caucasus, and Siberia $[1,17,19]$.

\section{Materials and Methods}

Nesting behavior of $O$. a. calcaratus was studied on the waste area of the cargo seaport $\left[44^{\circ} 30^{\prime} 3^{\prime \prime} \mathrm{N} 34^{\circ} 12^{\prime} 7^{\prime \prime} \mathrm{E}\right.$ ] near Yalta in June 1-10, 2010, May 27-June 8, 2011, on the dirt road in the Mys Martyan Nature Reserve $\left[44^{\circ} 30^{\prime} 34^{\prime \prime} \mathrm{N} 34^{\circ} 14^{\prime} 19^{\prime \prime} \mathrm{E}\right]$ in June 9, 2011, and on phrygana slopes in Lisya bay $\left[44^{\circ} 54^{\prime} 3^{\prime \prime} \mathrm{N}\right.$ $35^{\circ} 9^{\prime} 30^{\prime \prime} \mathrm{E}$ ] in the vicinities of the Karadag Nature Reserve in June 15-18, 2011. Nesting behavior of O. femoratus was studied on the meadow glade in Kharab-Tavel valley $\left[44^{\circ} 48^{\prime} 42^{\prime \prime} \mathrm{N}\right.$ $34^{\circ} 13^{\prime} 3^{\prime \prime} \mathrm{E}$ ] near the village of Krasnolesye in June 22-July 19, 2011. Behavior of the wasps was also observed at their watercollecting sites.

A total of 46 nests of $O$. a. calcaratus and 18 nests of O. femoratus were examined, and they were subjected to dissection at different stages of construction. The nests were dissected laterally, and plans of their construction were drawn on graph paper with compasses. Immature instars of the wasps and their prey were placed in glass tubes sealed with cotton plugs and were kept in outdoor conditions. Potential preys were sampled by sweeping the surrounding vegetation and identified after rearing to the imago stage in the laboratory. Soil samples were taken near the wasp nests. Granulometric analysis of these samples was made according to Kachinskiy's method [20].

All photos in the paper were made with Canon PowerShot A570 IS camera; drawings were made by outlining of the photos and the graph paper plans.

\section{Results}

\subsection{Nesting Biology of Odynerus albopictus calcaratus}

3.1.1. Description of the Nesting Area and Soil Substrate. The nests of $O$. a. calcaratus were found on three nesting sites. First site (Figure 1(a)) was the waste area covered by weed vegetation with coverage of $40-50 \%$ and predomination of Lolium rigidum Gaudin, Anisantha sterilis (L.) Nevski, and Hordeum murinum subsp. leporinum (Link) Arcang. (Poaceae). The nests were found to be strongly associated with areas with less grass coverage. Light clay loam soil slightly mixed with beach sand was revealed in this site (Table 1). The second site on the dirt road was devoid of vegetation; only a few herbs of Scleropoa rigida (L.) Griseb. (Poaceae) with total coverage less than 5\% were found there. The soil revealed at this nesting site was dense clay loam (Table 1). The third nesting site in Lisya bay was hill slopes covered by phrygana vegetation with coverage of 70$80 \%$ and predomination of Camphorosma monspeliaca L. (Chenopodiaceae), Thymus tauricus Klokov et Des.-Shost. (Lamiaceae), and Atraphaxis replicata Lam. (Polygonaceae). The soil revealed at this site was middle clay loam (Table 1). Thus, the nesting site and substrate preferences of $O$. $a$. calcaratus were relatively broad. A total of 29 nests were found at the first site, one nest at the second site, and 16 at the third site.

3.1.2. Nest Construction. Females started their nesting activity at the end of May. If the weather was not favourable, they rest on Lolium spikelets and waited for the sun to rise (Figure 1(b)). A female started her nesting by searching a place for the first nest. She rose her abdomen upward in the manner of females of Tropidodynerus interruptus (Brullé, 1832) [21], but not so high, and began to run around on the ground surface. She touched the ground with her antennae and very carefully searched the place without visible stones or other obstacles. This behavior lasted 10-15 minutes and finished by a round flight up to one meter in diameter. After the place had been chosen, the female flew to collect water in nearly situated small streamlets or puddles (Figure 1(c)). She often landed directly on the water surface and steped on it via surface tension. Then, she arrived to the nesting site with water in her crop and regurgitated it onto the ground surface (Figure $1(\mathrm{~d})$ ). After that, she began to excavate a vertical nest burrow and to construct the turret at the same time. She mixed water with soil, formed small mud pellets, retrieved them from the nest burrow, and laid them around its entrance without spaces between the pellets. After each mud pellet had been placed, she smoothed its inner surface with her mouthparts. By this way, the turret grew upwards and the burrow grew downwards at the same time. The depth of the completed burrow of O. a. calcaratus was $15-25 \mathrm{~mm}$. Completed turrets were short curved tubes 5-10 $\mathrm{mm}$ high, opened sideways (Figures 1(e) and 2(a)). After the turret had been completed, the female continued the excavation of the nest burrow. At this time, she also retrieved mud pellets from the nest, but these pellets were significantly bigger. She did not use them for turret but flew from the nest for few seconds and dropped them away. She also flew for water after each retrieving and dropping of several mud pellets. When the burrow had been completed, she laid an egg and started hunting. After provisioning, the female sealed the cell and usually the nest too. She demolished the turret and sealed the cell with its material. After that, she took mud in another place, usually in $10-15 \mathrm{~cm}$ from the nest, and completely sealed the nest burrow. All her building actions interchanged with flights for water. Two turrets damaged by rain during the observations were not repaired by the females. 


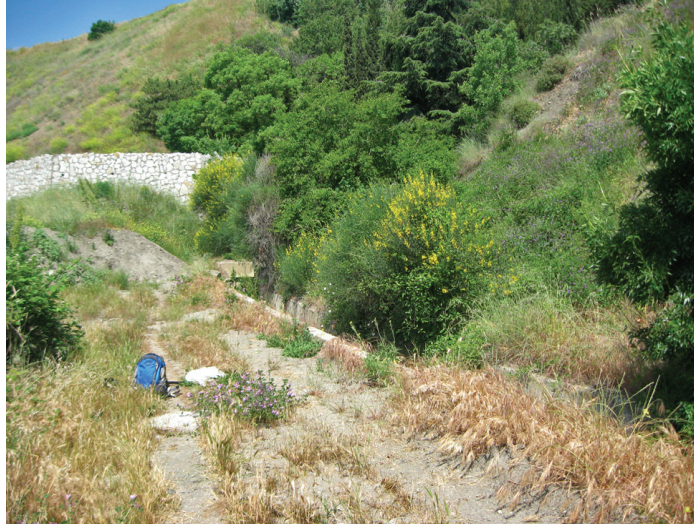

(a)

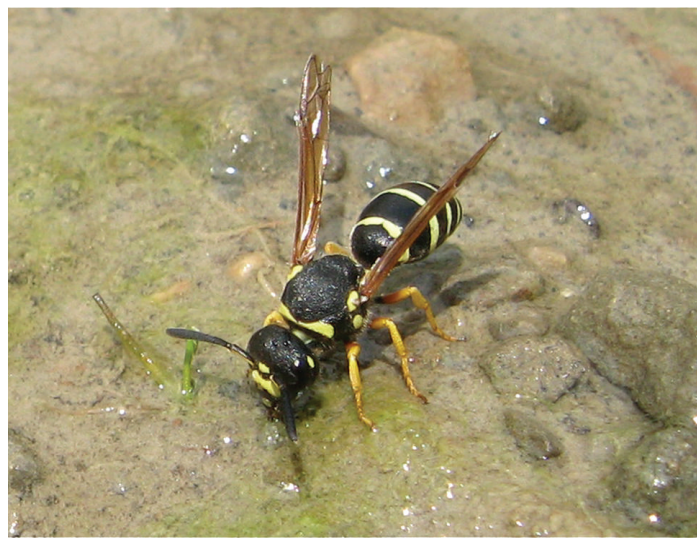

(c)

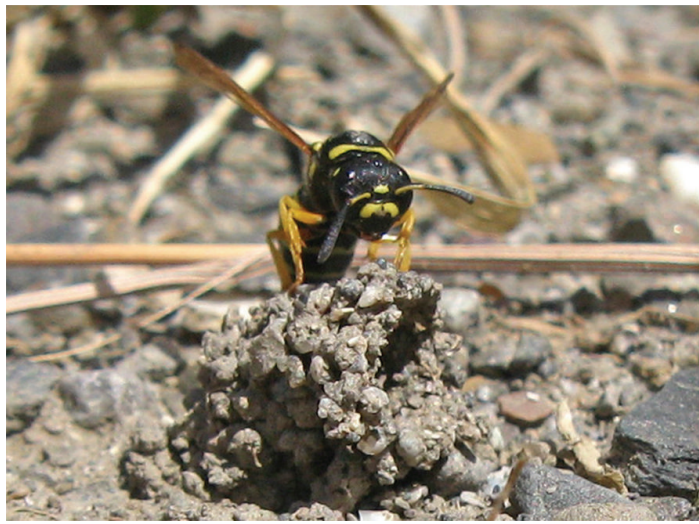

(e)

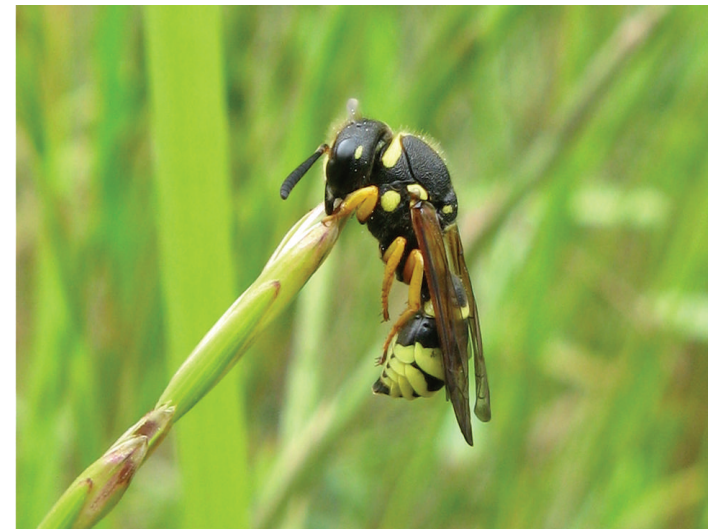

(b)

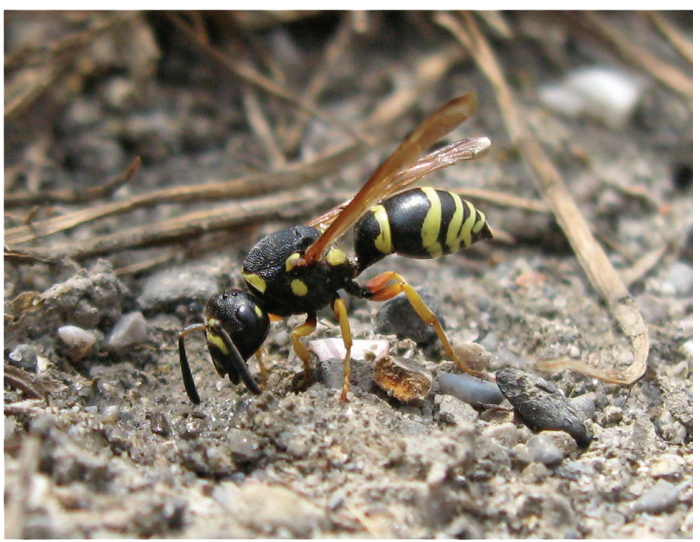

(d)

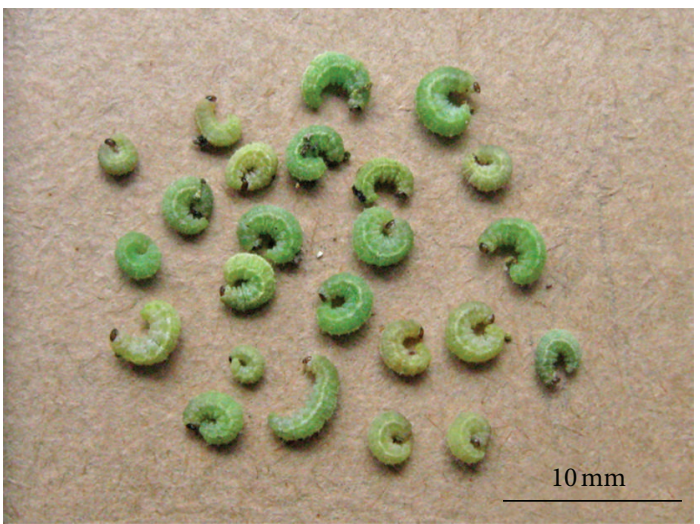

(f)

Figure 1: Nesting biology of Odynerus albopictus calcaratus. (a) Nesting site. (b) Female resting on Lolium spikelet. (c) Female collecting water. (d) Female starting the excavation of the nest burrow. (e) Female on the nest before entering inside. (f) Hypera larvae revealed in one cell of a nest.

TABLE 1: Parameters of the soil substrate containing the nests of Odynerus albopictus calcaratus and Odynerus femoratus at four nesting sites.

\begin{tabular}{lccc}
\hline Nesting site & Density $\left(\mathrm{g} / \mathrm{cm}^{3}\right)$ & Content of physical clay parts $<0.01 \mathrm{~mm}(\%)$ & Granulometric class \\
\hline \multicolumn{2}{c}{ Odynerus albopictus calcaratus } \\
Cargo seaport near Yalta & 2.60 & 21.14 & Light clay loam \\
Mys Martyan Nature Reserve & 2.50 & 49.31 & Dense clay loam \\
Lisya bay & 2.67 & 40.36 & Middle clay loam \\
\hline & \multicolumn{3}{c}{ Odynerus femoratus } \\
Kharab-Tavel valley near Krasnolesye & 2.50 & 28.29 & Light clay loam \\
\hline
\end{tabular}


3.1.3. Structure of Complete Nests, Immature Instars and Development. Complete nests of O. a. calcaratus contained 1-2 cells (Table 2). The nest burrow of complete nests was entirely filled with mud. The plug was flat or towered for $1-2 \mathrm{~mm}$ above the ground surface (Figure 2(b)). The first cell in each nest had inclined and somewhat curved configuration; the second cell, if present, was more or less vertical (Figure 2(b)). An egg was attached to the cell wall by a filament (Figure 2(a)). Two eggs were observed; one was attached to a tiny root hidden inside the cell wall and another one to a bit of a snail shell which was also a part of the inner cell wall. The inner walls of the cell were smooth and polished by the female. All inner volume of a freshly sealed cell was filled with compactly stored curculionid larvae; they were laid transversally across the cell and glued with each other. The number of prey in two cells was 21 and 24 . The larva ate prey during five days and then spun a cocoon. Before the first cocoon layer was made, the larva stored prey remains and their feces at the top of the cell near the plug. These wastes were separated from the remaining part of the cell with a first thin yellowish cocoon part, consisting only of silk. After that, the larva constructed the second, thick layer of the cocoon entirely covering the first one as well as the bottom of the cell and its lateral walls. This layer was made with the help of fluid secretion which penetrated into the cell walls and made them durable and waterproof. After construction of the cocoon, the meconium was discharged at the bottom of the cell and spread all over it as well as over the lower half of the lateral walls of the cell. Then, the larva transformed into the prepupal stage and became convolute. The inner volume of the cocoon significantly exceeded the size of the prepupa (Figure 2(c)). The hibernation occurred at the prepupal stage. Next year, after the winter diapause, the prepupa unrolled and became straight. Adult wasps emerged in mid-May. The observations showed that $O$. a. calcaratus is an univoltine species.

3.1.4. Trophic Links. Females of O. a. calcaratus hunted for larvae of curculionid beetles (Coleoptera: Curculionidae). The larvae of alfalfa weevil, Hypera variabilis (Herbst, 1795), were recorded as the wasp prey at the first nesting site, near Yalta (Figure 1(f)). The wasps collected them on inflorescences of hybrid alfalfa, Medicago $\times$ varia Martyn (Fabaceae). Another species of Hypera fed on sickle alfalfa (Medicago falcata L.) was recorded as the prey at the third site, in Lisya bay. This species was not reared to imago and so it was not identified. The wasp prey at the second nesting site was not detected. Feeding of the adult wasps was observed on flowers of Dorycnium pentaphyllum subsp. herbaceum (Vill.) Rouy (Fabaceae), Thymus tauricus, Reseda lutea L. (Resedaceae), Scrophularia rupestris Willd. (Scrophulariaceae), and rarely on Ornithogalum pyrenaicum L. (Asparagaceae) and Malva erecta J. Presl et C. Presl (Malvaceae).

3.1.5. Reproductive Success. Only five nests of O. a. calcaratus were successful among the 46 examined (Table 2). The other 41 nests were abandoned by females before egg laying, usually long before the burrow was completed. Most females that abandoned their nests found an obstacle (i.e., small

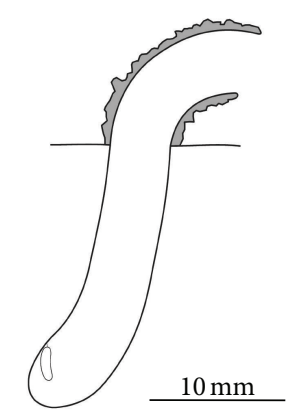

(a)

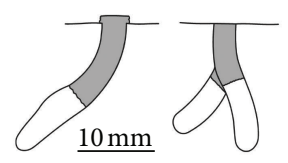

(b) (c)

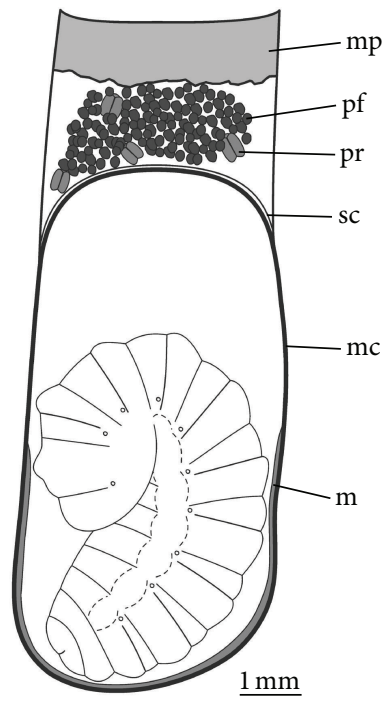

FIGURE 2: Nesting biology of Odynerus albopictus calcaratus. (a) Profile of one-celled nest illustrating the location of egg and configurations of the cell and the turret. (b) Profiles of one- and two-celled sealed nests. (c) Profile of the sealed cell illustrating the construction of the cocoon and the position of the prepupa inside it: $\mathrm{mp}$-mud plug; pf-prey feces; pr-prey remains; sc-silk cocoon part; $\mathrm{mc}-$ mud cocoon part; $\mathrm{m}-$ meconium.

stones, wood pieces, plastic bits) across the burrow. However, some females left their nests without any visible reasons. Five completed and sealed nests contained six cells; five of them were successful. One cell (in the nest at the second nesting site) was damaged by cleptoparasitic flies (Diptera: Sarcophagidae: Miltogramminae). Five puparia of these flies were found in the cell, but adult flies were not reared.

3.1.6. Male Behavior. Males spent most of their time near the nests. They made patrolling flights along nesting sites and sometimes stayed on the ground surface and waited for females. Males indiscriminately attacked any female arriving at the nesting site, but all of the observed attacks did not continue by courtship. Some males were observed attacking the water-collecting females. Copulation was not observed.

\subsection{Nesting Biology of Odynerus femoratus}

3.2.1. Description of the Nesting Area and Soil Substrate. The nests of $O$. femoratus were revealed on the meadow glade surrounded by a broad-leaved forest. The gramineous vegetation on this glade was very dense; the coverage reached up to $100 \%$. However, the nests were situated on a grassing dirt road crossing the glade (Figure 3(a)), and the nesting area was characterized by less coverage $(80-90 \%)$ with predomination of Festuca valesiaca Gaudin (Poaceae). The nests were found exactly between the clumps of this plant species. The other part of the glade was densely covered with grass, except for one spot with Rhinanthus angustifolius C. C. Gmel. (Orobanchaceae) where the other herbs were depressed and 
TABLE 2: Number of cells in nests and nesting success of Odynerus albopictus calcaratus and Odynerus femoratus.

\begin{tabular}{lcccccc}
\hline Species & $\begin{array}{c}\text { Number of } \\
\text { successful nests }\end{array}$ & \multicolumn{2}{c}{$\begin{array}{c}\text { Number of cells per nest } \\
\text { Min.-Max. }\end{array}$} & $\begin{array}{c}\text { Number of } \\
\text { successful cells }\end{array}$ & $\begin{array}{c}\text { Number of } \\
\text { damaged cells }\end{array}$ & $\begin{array}{c}\text { Number of vacant } \\
\text { nests without cells }\end{array}$ \\
\hline $\begin{array}{l}\text { Odynerus albopictus } \\
\text { calcaratus }\end{array}$ & 5 & $1-2$ & $1.2 \pm 0.2$ & 5 & 1 & 41 \\
Odynerus femoratus & 10 & $1-10$ & $4.0 \pm 0.1$ & 22 & 18 & 8 \\
\hline
\end{tabular}

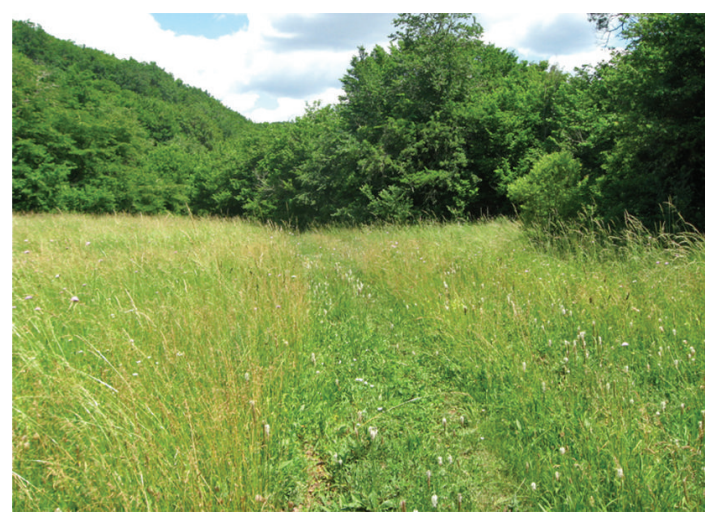

(a)

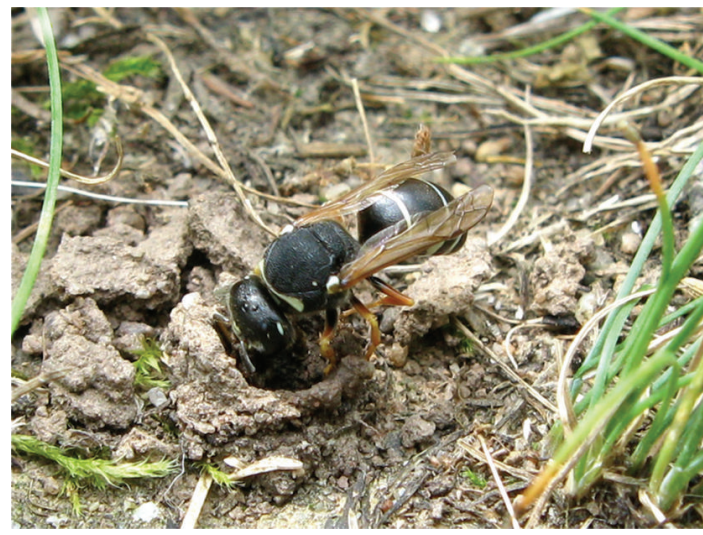

(c)

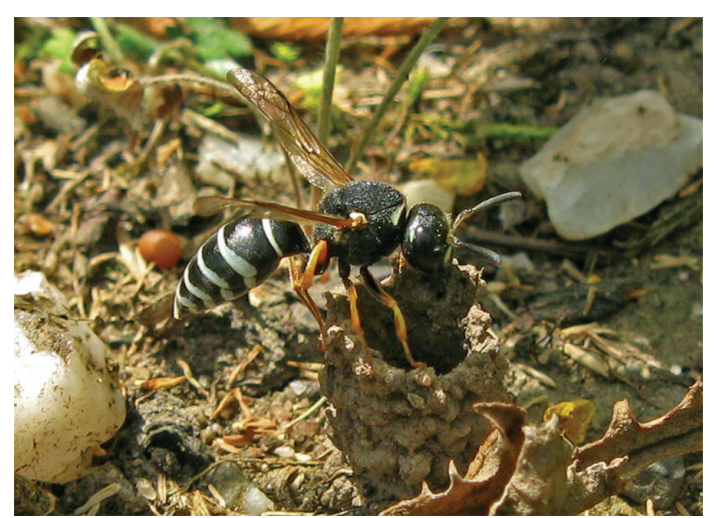

(b)

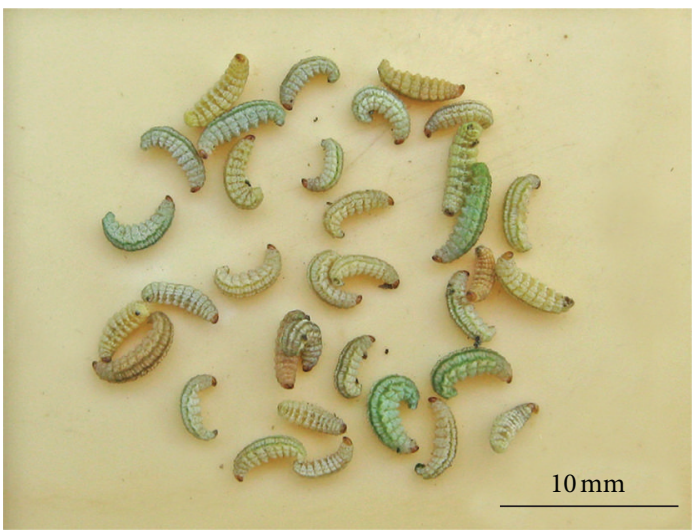

(d)

Figure 3: Nesting biology of Odynerus femoratus. (a) Nesting site. (b) Female retrieving a mud pellet from the nest burrow. (c) Female entering the nest with broken turret. (d) Hypera larvae revealed in one cell of a nest.

had low coverage. Formerly, the glade was the bottom of a small river. The soil revealed at this site was light clay loam (Table 1) with a large amount of alluvial material (i.e., pebbles and ground stones).

3.2.2. Nest Construction. Females started their nesting activity at mid-June. The method of construction of the nest is similar to O. a. calcaratus; however, searching a place for the nest and sealing the nest were not observed. Females flew for water to puddles on the dirt road near the nesting site. They also excavated the nest burrow with retrieving the pellets of two distinct sizes: small ones were used for the turret and big ones (Figure 3(b)) were dropped away one meter from the nest. The depth of the burrow was $20-45 \mathrm{~mm}$. The main difference between these species was that the females of $O$. femoratus built straight vertical turrets, which were longer than in O. a. calcaratus (12-18 $\mathrm{mm}$ high), but were also without spaces between the pellets (Figures 3(b) and 4(a)). These turrets were not damaged by rain because they were hidden under the grass. However, one turret was damaged by a bicyclist and was not repaired by the female (Figure 3(c)).

3.2.3. Structure of Complete Nests, Immature Instars, and Development. Complete nests of O. femoratus contained 1-10 cells (Table 2 ). The nest plug was usually towered for 1-2 $\mathrm{mm}$ above the ground surface (Figure $4(\mathrm{~b})$ ). The nest burrow of complete nests was not entirely filled with mud; several internodes were found in some nests. However, the sealed burrow of the largest nests of 10 cells did not contain any empty spaces, so, it was impossible even to understand the order of the cells in this nest. In the other nests, the first 


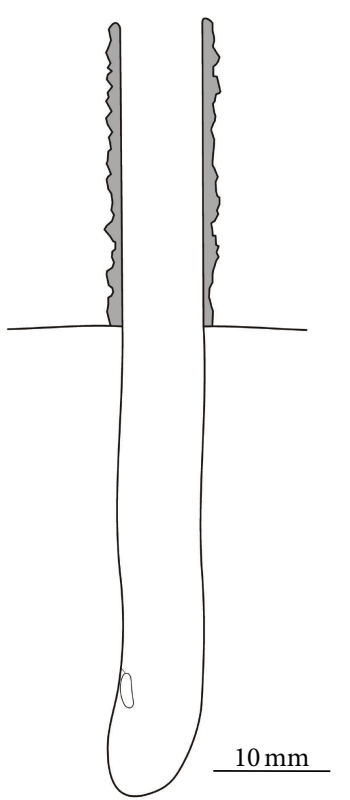

(a)

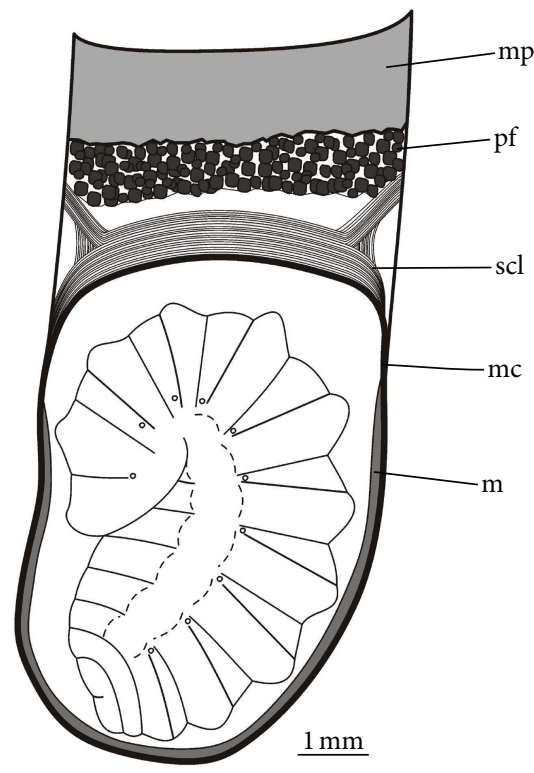

(c)
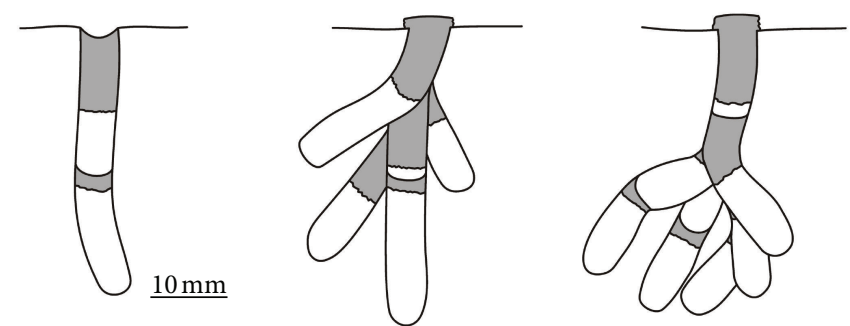

(b)

Figure 4: Nesting biology of Odynerus femoratus. (a) Profile of one-celled nest illustrating the location of egg and configurations of the cell and the turret. (b) Profiles of one-, four-, and seven-celled sealed nests. (c) Profile of the sealed cell illustrating the construction of the cocoon and the position of the prepupa inside it: $\mathrm{mp}$-mud plug; pf—-prey feces; scl—silk cocoon layers; mc—mud cocoon part; $\mathrm{m}$-meconium.

cell was usually vertical or only slightly inclined; the other cells, if present, were built more or less inclined laterally. An egg was attached to the cell wall by a filament (Figure 4(a)). The places where the eggs were attached did not contain any roots or other material different from smoothed inner mud walls of the cell. All inner volume of a freshly sealed cell was filled with compactly stored curculionid larvae; they were laid transversally across the cell and glued with each other, as in O. a. calcaratus. The number of prey in three cells was 14, 30, and 34. As in O. a. calcaratus, the larva stored prey remains and their feces at the top of the cell before the first cocoon layer was made. However, it separated the wastes by multilayered silk cocoon part (Figure 4(c)). The inner, mud-containing part of the cocoon was similar to that in $O$. a. calcaratus. The meconium of $O$. femoratus was spread not only all over the bottom of the cell but also along nearly the entire surface of its lateral walls. The inner volume of the cocoon was smaller than in O. a. calcaratus in comparison with the larva size (Figure 4(c)). The hibernation occurred also at the prepupal stage. However, only five wasps emerged in 2012 from seven prepupae obtained in 2011. Two other prepupae continued their hibernation for a second year but died in May, 2013, as pupae. As well as O. a. calcaratus, O. femoratus is an univoltine species.

3.2.4. Trophic Links. Females of O. femoratus hunted also for larvae of curculionid beetles of the genus Hypera (Figure 3(d)). Two species were recognized among the prey from the nest cells. The first one was reared to imago and identified as Hypera arator (Linnaeus, 1758); females collected its larvae on Stellaria graminea L. (Caryophyllaceae). The second species was not reared and identified; females collect its larvae on Trifolium campestre Schreb. (Fabaceae). Feeding of the adult wasps was observed on flowers of Sambucus ebulus L. (Adoxaceae), Butomus umbellatus L. (Butomaceae), Medicago falcata L., T. campestre (Fabaceae), Potentilla argentea L., Potentilla reptans L. (Rosaceae), and very rarely on Leucanthemum ircutianum DC. (Asteraceae), Knautia arvensis (L.) Coult. (Caprifoliaceae), and S. graminea.

3.2.5. Reproductive Success. Ten nests of O. femoratus were successful among the 18 examined (Table 2). Other eight nests were abandoned by females before egg laying. Ten complete and sealed nests contained 40 cells; 22 of them 
were successful. Other cells were damaged by rain moisture (15 cells) or tachinid flies (Diptera: Tachinidae) (one cell). It was impossible to establish whether the fly was the parasite of the wasp or it came to the cell with a prey. One cell contained dead prepupa in the cocoon. One cell, examined directly after it had been sealed by a wasp, did not even contain an egg. It is possible that part of the cells which were damaged by rain moisture was also without eggs. These cells contained rotten and musty prey, and it was not possible to find an egg among them. The cocoons of Bathyplectes sp. (Hymenoptera: Ichneumonidae) were also found in the cells. These parasitoids of curculionid beetles which have been already found in the nests of other weevil-hunting species $[14,22]$ did not cause wasp mortality.

3.2.6. Male Behavior. Males of O. femoratus occurred only near the nests. They investigated surrounding vegetation and attacked all females nearly. An unusual large amount of males was discovered at the nesting site previously, in 2004. More than 100 males were seen investigating the grass vegetation on one area about $15 \mathrm{~m}$ long and $5 \mathrm{~m}$ wide. This area had low grass coverage due to suppression of all plants by Rhinanthus roots. The nests were not found that year (2004). The copulation was not observed either.

\section{Discussion}

The nests of $O$. a. calcaratus and O. femoratus were described for the first time, and their nesting habits appear to be typical to the genus as a whole (except for O. cinnabarinus and $O$. erythrogaster). Unfortunately, the nesting of several species studied previously had been described fragmentally. However, at least six well-studied species of two subgenera can be compared: O. dilectus, O. femoratus, and O. spinipes (subgenus Odynerus s. str.) and O. a. calcaratus, O. eburneofasciatus, and $O$. reniformis (subgenus Spinicoxa). The nest construction is very similar in all species listed previously; differences can be found mainly in the number of cells per nest and in the configuration of the turrets.

The wasps of the subgenus Odynerus s. str. seem to make large number of cells in their nests: 1-7 (usually, 5-6) in $O$. spinipes $[8,10], 4-7$ in $O$. dilectus [14], and $1-10$ in $O$. femoratus (present observation). The wasps of the subgenus Spinicoxa make nests with significantly less number of cells: 1-2 in O. eburneofasciatus [16] and O. a. calcaratus (present observation) and 1-4 (usually, 2-3) in O. reniformis $[10,12]$. Thus, the nests with small number of cells can be regarded as one of the characters of the subgenus Spinicoxa. The nests with small number of cells can be useful to protect the brood against parasites by the way of deconcentration of the cells. However, the nests with large number of cells increase nesting efficiency by the way of saving the time required for the excavation of the nest burrow and for the construction of the turret. An interesting association can be speculated in relation to time saving: the species with large number of cells in their nests (O. dilectus, O. femoratus, and O. spinipes, as well as $O$. reniformis) built longer turrets $(2-3 \mathrm{~cm}$ or longer) than the species (O. a. calcaratus and O. eburneofasciatus) with 1-2 cells per nest which build the turrets about $1 \mathrm{~cm}$ long.

The turrets of Odynerus wasps can be constructed with or without spaces between mud pellets. Most species listed previously make turrets without these spaces, except for $O$. spinipes [9-11]. The other principal character of the turrets which is different in various species is their configuration. First of all, the form of the turret can be distinct due to the type of nesting substrate surface. Some species, such as $O$. spinipes and $O$. simillimus, nest on vertical surfaces of clay cliffs $[8,10,11,23]$, while the nests of $O$. dilectus and $O$. eburneofasciatus [14-16], as well as of O. femoratus and O. $a$. calcaratus (present observation), were recorded on relatively horizontal surfaces. Nesting on both vertical and horizontal surfaces was recorded in O. reniformis and O. melanocephalus $[7,10,12,13]$. Thus, the choice of vertical or horizontal substrate does not depend on subgeneric placement of the species; the wasps nesting on horizontal, vertical, or both horizontal and vertical surfaces can be found in both Spinicoxa and Odynerus s. str. subgenera. The turrets of the nests built on vertical surfaces are always curved and opened downward. The turrets of the nests built on horizontal surfaces can be straight and opened upward (as in O. femoratus) or curved and opened sideward (as in O. a. calcaratus). Turrets of two distinct architectural forms can be found even among the nests of one species [15]. However, the species in the subgenus Odynerus s. str. nesting on horizontal surfaces $(O$. dilectus and $O$. femoratus) usually build straight turrets opened upward, and the ones in the subgenus Spinicoxa (O. a. calcaratus and O. eburneofasciatus) always build curved turrets opened sideward.

The function of the turrets of the ground nesting wasp nests has been speculated to have three main functions [24]: (1) a barrier to nest parasites and predators; (2) a barrier to dust and water, which controls the inner microclimate of the nest; and (3) a landmark helping the wasp to find its nest. The second and the third hypotheses can be discarded, particularly in the case of O. a. calcaratus and O. femoratus. Rain water destroys the turrets of O. a. calcaratus; the turrets of $O$. femoratus are protected against the rain by the grass and thus cannot be used as landmarks. As for the first hypothesis, it is well known that specialized parasites (e.g., gold wasps) enter into the nests with turrets without any problems $[9,10$, 16]. The puparia of sarcophagid flies discovered in the cell of $O$. a. calcaratus were also in the nest with intact turret. The main function of the turret seems to protect the nest against ants [25]. These insects have never been observed entering the nests of Odynerus with intact turrets during the present observations. They entered the nests only when the turrets had been destroyed by rain or human impact. In two instances, workers of the ant species, Cataglyphis aenescens (Nylander, 1849) (Hymenoptera: Formicidae), were observed also disturbing one female of $O$. a. calcaratus: they attacked her and stole the water which had been regurgitated onto the ground surface. Such ant behavior was observed at the beginning of nesting activity of the wasp when the turret was not completed. 
The fact that two O. femoratus prepupae extended their diapause into a second year is notable and can be explained by the climatic conditions of the nesting area: the habitat of the species near Krasnolesye is quite wet. The rains can significantly reduce the reproductive success of the wasp: the wasp larva must hatch out and complete feeding and cocooning before any rain will fall, because only cocooned larva is secured from water and moulds. If all wasps in the nests will emerge at the same year and this year will be rainy, females will have very low reproductive success.

\section{Acknowledgments}

The author is greatly indebted to Boris A. Korotyaev (Zoological Institute of the Russian Academy of Sciences, Saint Petersburg, Russia) for the identification of the weevils, Anna V. Zamotayeva (Nikitskiy Botanical Garden, National Scientific Center, Yalta, Ukraine) for the help with the soil analysis, Alexander V. Amolin (Donetsk National University, Donetsk, Ukraine) for providing certain references, and the three anonymous reviewers for helpful suggestions on a previous version of this paper.

\section{References}

[1] N. V. Kurzenko, "A review of the wasps of the family Eumenidae (Hymenoptera, Vespoidea) of the fauna of the USSR. Genera Paravespa Rad., Paragymnomerus Blüthg., Tropidodynerus Blüthg., Gymnomerus Blüthg. and Odynerus Latr.” Entomologicheskoye Obozreniye, vol. 56, no. 3, pp. 676-690, 1977 (Russian).

[2] J. Gusenleitner, "Bestimmungstabellen mittel-und südeuropäischer Eumeniden (Vespoidea, Hymenoptera). Teil 14: Die Gattungsschlüssel und die bisher in däeser Reihe nicht behandelten Gattungen und Arten," Linzer Biologische Beiträge, vol. 32, no. 1, pp. 43-65, 2000.

[3] A. V. Amolin, Ecologically-Faunistic Review of the Wasps of the Subfamily Eumeninae (Hymenoptera: Vespidae) of the Southeastern Ukraine, Donetsk National University, Donetsk, Ukraine, 2009 (Russian).

[4] J. M. Carpenter, "A synonymic generic checklist of the Eumeninae (Hymenoptera: Vespidae)," Psyche, vol. 93, pp. 61-90, 1986.

[5] J. P. Spradbery, Wasps: An Account of the Biology and Natural History of Solitary and Social Wasps, University of Washington, Washington, DC, USA, 1973.

[6] J. H. Fabré, Instinct and Temperaments of Insects, vol. 1, Terra, Moscow, Russia, 1993.

[7] G. Adlerz, "Iakttagelser över solitära getinger," Arkiv för Zoologi, vol. 3, no. 17, pp. 1-64, 1907.

[8] W. S. Bristowe, "Notes on the habits and prey of twenty species of British hunting wasps," Proceedings of the Linnean Society of London, vol. 160, pp. 12-37, 1948.

[9] J. P. van Lith, "Hoplomerus (Hoplomerus) spinipes (L.) en Hoplomerus (Spinicoxa) reniformis (Gmel.)," Entomologische Berichten, vol. 16, no. 12, pp. 259-263, 1956.

[10] P. Miotk, "Zur Biologie und Ökologie von Odynerus spinipes (L.) und O. reniformis (Gmel.) an den Losswanden des Kaiserstuhls (Hymenoptera: Eumenidae)," Zoologische Jahrbücher. Abteilung Für Systematik Ökologie Und Geographie Der Tiere, vol. 106, no. 3, pp. 374-405, 1979.
[11] D. Mader, "Nestbauten der Schornstein-Lehmwespe Odynerus spinipes in Buntsandstein und Quartär in Eifel, Saarland und Pfalz," Dendrocopos, vol. 26, no. 2, pp. 216-234, 1999.

[12] E. T. Nielsen, "Sur les habitudes des Hyménoptères aculéates solitaires. II, (Vespidae, Chrysididae, Sapygidae et Mutillidae)," Entomologiske Meddelelser, vol. 18, pp. 84-174, 1932.

[13] G. Olberg, Das Verhalten Der Solitären Wespen Mitteleuropas (Vespidae, Pompilidae, Sphecidae), Wissenschaften, Berlin, Germany, 1959.

[14] G. E. Bohart, F. D. Parker, and V. J. Tepedino, "Notes on the biology of Odynerus dilectus [Hym.: Eumenidae], a predator of the alfalfa weevil, Hypera postica [Col.: Curculionidae]," Entomophaga, vol. 27, no. 1, pp. 23-31, 1982.

[15] B. D. Schaber, "Observations on nesting behavior and turret construction by Odynerus dilectus," Canadian Entomologist, vol. 117, no. 9, pp. 1159-1161, 1985.

[16] V. Haeseler, "Die Odynerus-Arten O. eburneofasciatus Dusmet 1903, O. antigai Dusmet 1903 sowie O. annulicornis Blüthgen 1956 und zur Biologie von O. eburneofasciatus Dusmet 1903 (Vespoidea: Eumenidae)," Linzer Biologische Beiträge, vol. 29, no. 1, pp. 151-166, 1997.

[17] P. Blüthgen, "Die Faltenwespen mitteleuropas (Hymenoptera, Diploptera)," Abhandlungen Der Deutschen Akademie Der Wissenschaften Zu Berlin. Klasse Für Chemie, Geologie Und Biologie, no. 2, pp. 1-252, 1961.

[18] F. D. Parker, "Nests and nest associates of two "red" Odynerus wasps (Hymenoptera: Eumenidae)," Journal of the Kansas Entomological Society, vol. 57, no. 3, pp. 521-525, 1984.

[19] J. Gusenleitner, "Bestimmungstabellen mittel-und südeuropäischer Eumeniden (Vespoidea, Hymenoptera). Teil 8: Die Gattungen Odynerus Latreille 1802, Gymnomerus Blüthgen 1938, Paragymnomerus Blüthgen 1938 und Tropidodynerus Blüthgen 1939," Linzer Biologische Beiträge, vol. 30, no. 1, pp. 163-181, 1998.

[20] A. F. Vadunina and Z. A. Korchagina, Methods of the Studying of Physical Properties of Soils Edition, Agroprom izdat, Moscow, Russia, 3rd edition, 1986.

[21] W. Arens, "Zum Verhalten von Tropidodynerus interruptus (Brullé 1832) (Vespoidea, Eumenidae) und seines Brutparasiten Chrysis jaxartis Sem. am Nest," Linzer Biologische Beiträge, vol. 31, no. 1, pp. 147-158, 1999.

[22] A. V. Fateryga, "Nesting of the wasp Gymnomerus laevipes (Hymenoptera, Vespidae) in the Crimea," Vestnik Zoologii, vol. 46, no. 3, pp. 229-238, 2012 (Russian).

[23] K. Drogoszewski, "Eine neue Odynerus-Art (Hym. Vespidae) aus Polen," Polskie Pismo Entomologiczne, vol. 12, no. 1-4, pp. 303-304, 1934.

[24] D. P. Cowan, "The solitary and presocial Vespidae," in The Social Biology of Wasps, K. G. Ross and R. W. Matthews, Eds., pp. 3373, Cornell University Press, Ithaca, NY, USA, 1991.

[25] A. V. Fateryga, "The observations on the nesting behavior of the solitary wasp Tropidodynerus interruptus (Brullé, 1832) (Hymenoptera, Vespidae, Eumeninae) in the Crimea," Yevraziatskiy Entomologicheskiy Zhurnal, vol. 8, no. 4, pp. 381-385, 2009 (Russian). 

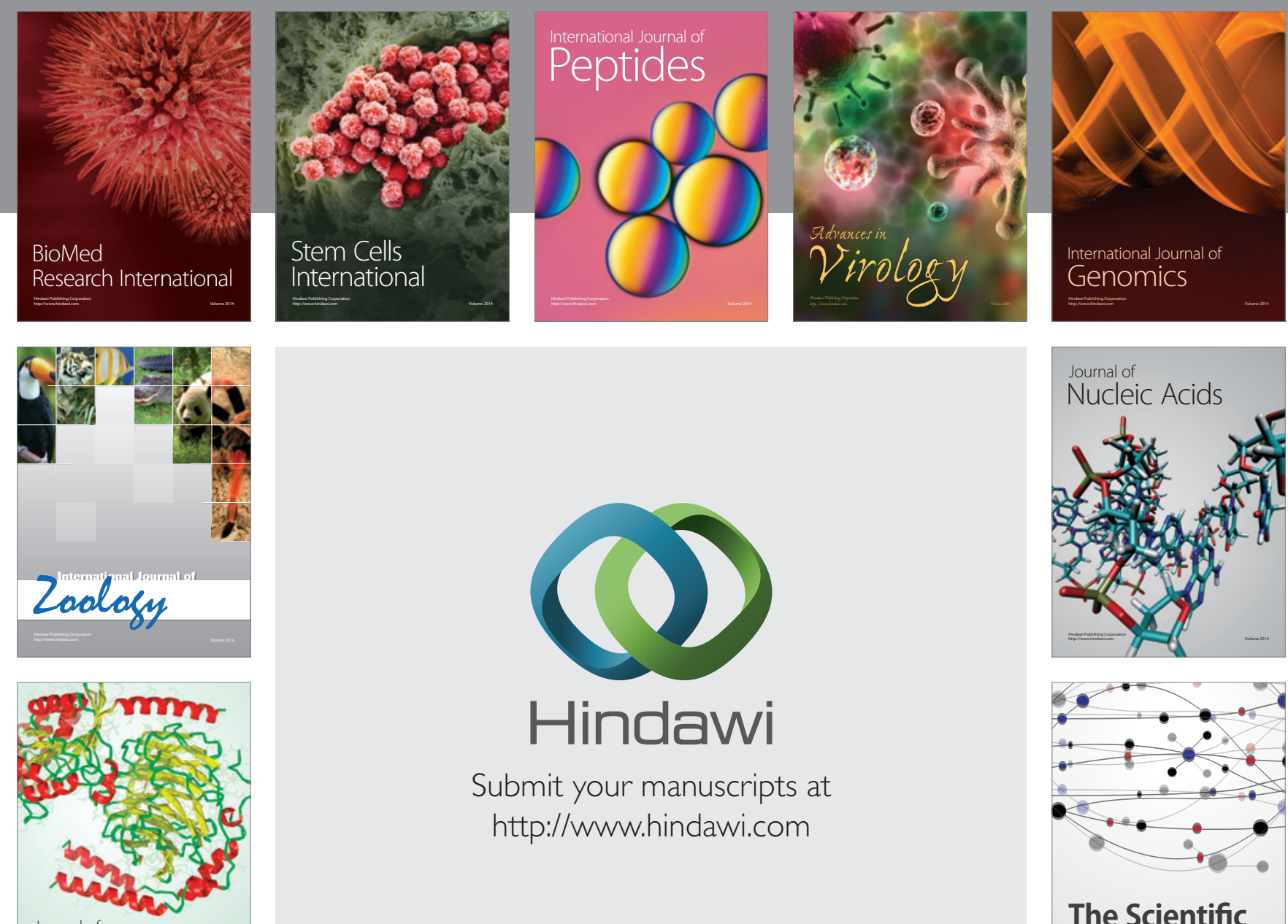

Submit your manuscripts at

http://www.hindawi.com

Journal of
Signal Transduction
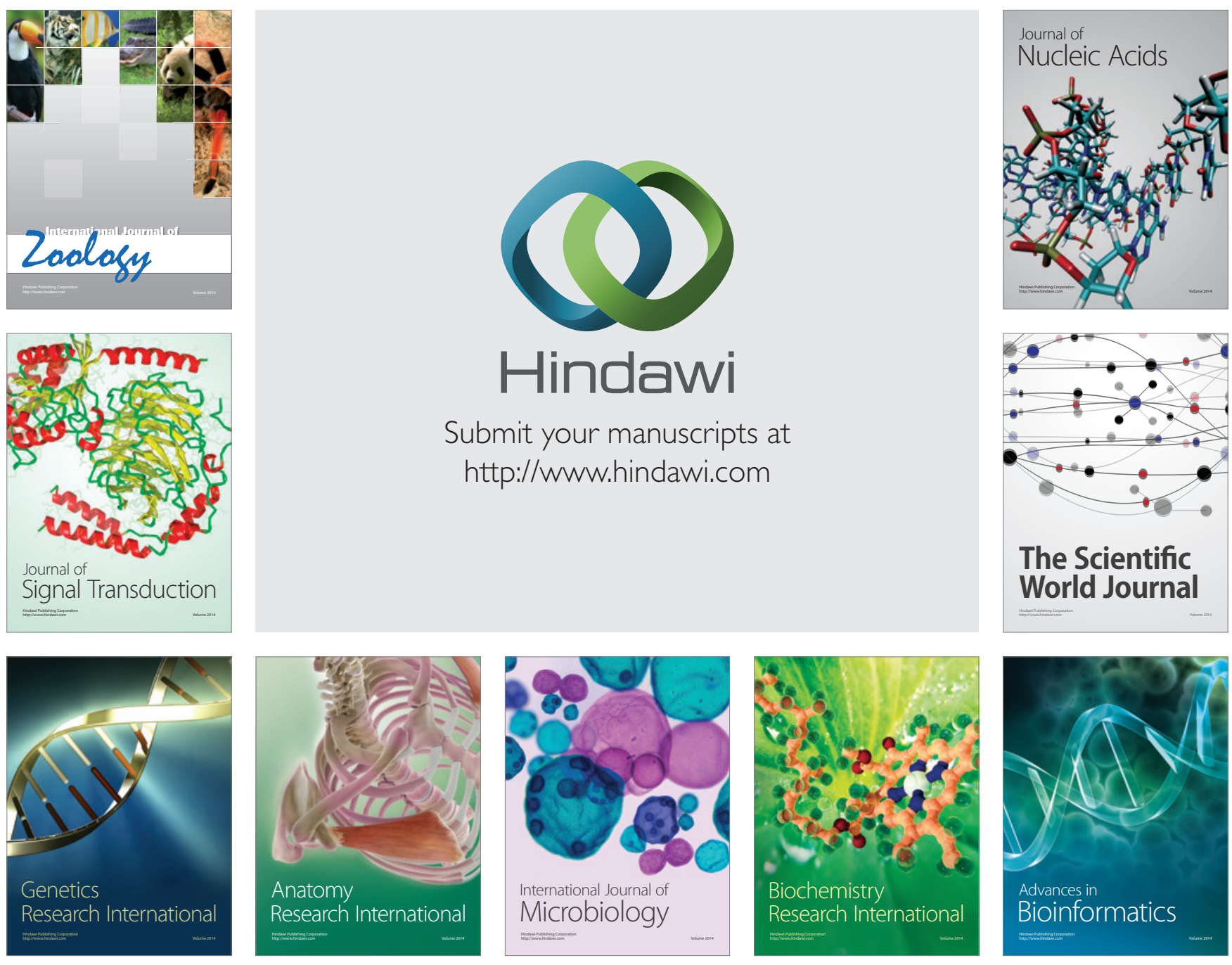

The Scientific World Journal
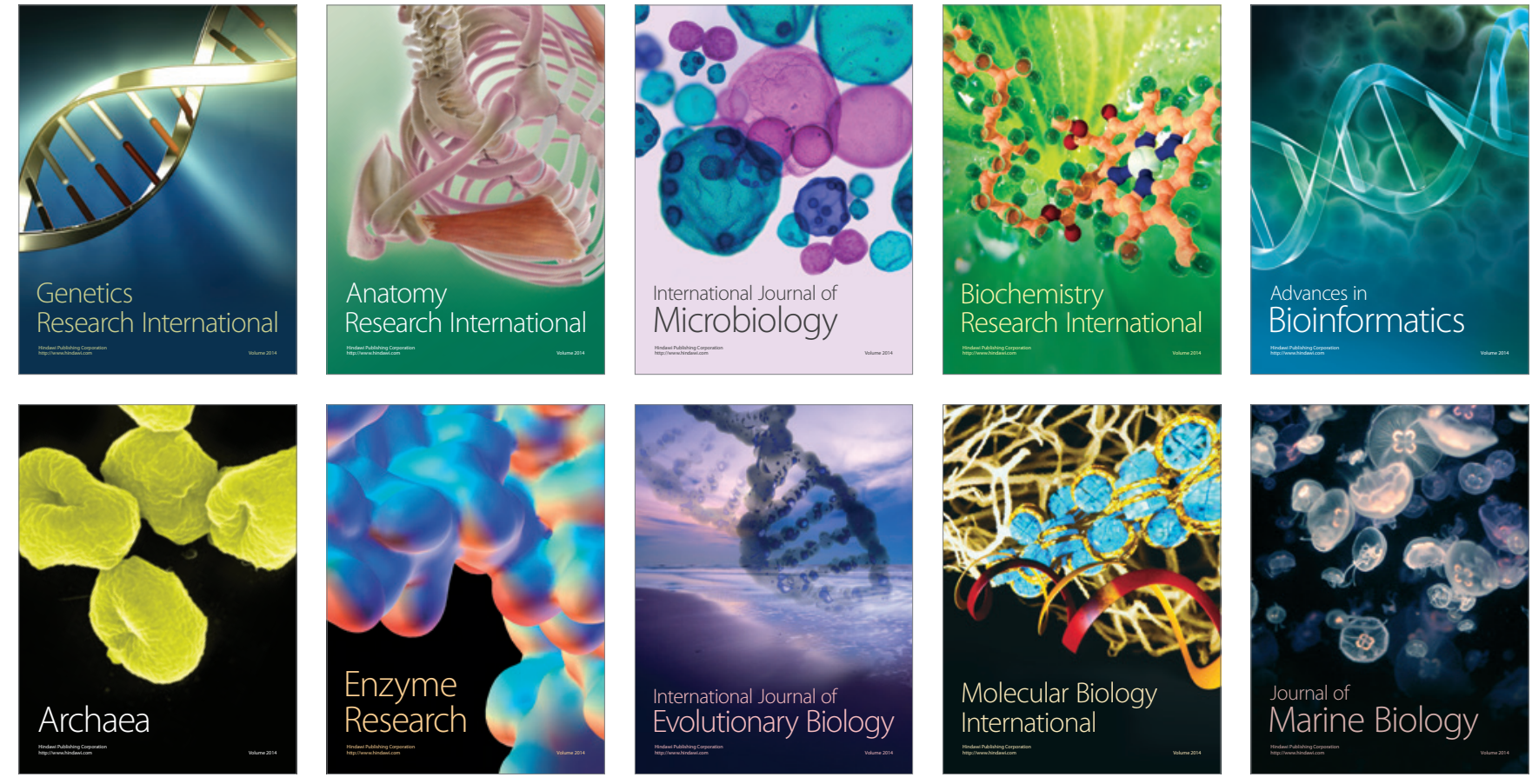